\title{
PARAMETER KEBENARAN ILMU PENGETAHUAN (SAINS) DALAM AL-QUR'AN
}

\author{
Ibnul Arobi*
}

\begin{abstract}
Abstrak: Kebenaran suatu ilmu pengetabuan benar-benar dapat diketahui kebenarannya. Kebenaran merupakan puncak kajian epistemology yang bermuara pada metafisika. Esensi suatu kebenaran ilmu adalab cocoknya informasi, atau teori dengan kenyataan objek sndiri. Dalam aspek-aspek dunia metafisis dan realitas mutlak transcendental, parameter kebenaran itu adalab teks wabyu (al-Qur'an dan Hadith) yang maknanya diketahui secara pasti menurut standar Ijma' dan logika untuk derajat "normal". Parameter kebenaran suatu ilmu pengetabuan dapat dibuktikan dalam al-Qur'an, didalamnya memuat berbagai ilmu pengetabuan yang kebenarannya mutlak serta keasliannya yang tak dapat disangsikan lagi dan juga telab memberikan kedudukan istimewa kepada al-Qur'an diantara kitabkitab suci yang lain.
\end{abstract}

Kata Kunci: Al-Qur'an, Ilmu Pengetabuan, Kebenaran, Teori Religiusme.

\section{Pendahuluan}

Al-Qur'an al-Karim adalah kitab standar kehidupan umat manusia dari bangsa dan penganut faham apa pun. Al-Qur'an adalah standar (rujukan) umat manusia yang hidup di segala zaman dan ruang. Bagaimana tidak, ternyata ayat-ayat Al Qur'an yang diturunkan di abad ke 7 Masehi sesuai dengan ilmu pengetahuan modern yang baru-baru

* Dosen Fak. Tarbiyah Institut Ilmu keislaman Zainul hasan Genggong Kraksaan Probolinggo 
ini ditemukan oleh manusia. Padahal pada masa itu ilmu pengetahuan belum berkembang. Ini membuktikan bahwa al- Qur'an adalah mukjizat.

Secara apriori mengasosiasikan al-Qur'an dan Sains, adalah mengherankan, apalagi jika asosiasi tersebut berkenaan dengan hubungan harmonis dan bukan perselisian antara al-Qur'an dan sains. Al-Qur'an mengajak memperdalam Sains, ia memuat bermacam-macam pemikiran tentang fenomena alam, dengan perinci yang menerangkan hal-hal yang pasti cocok dengan Sains modern. Misalnya; mengenai penciptaan alam, astronomi, keterangan tentang bumi, hewan-hewan, tumbuh-tumbuhan dan penciptaan manusia.

\section{Definisi Kebenaran dan Ilmu Pengetahuan}

Secara umum definisi yang standar mengenai kebenaran diartikan sebagai kesesuaian antara pikiran dan kenyataan. John Dewey menyebutkan bahwa yang dimaksud kebenaran adalah "apa yang membawa hasil”. Suatu pertimbangan itu dikatakan "benar" jika telah mencapai hasil yang berguna. Sebaliknya, pertimbangan itu "salah" jika dengannya dihasilkan hal yang merugikan. ${ }^{1}$ Dengan kata lain, bahwa kebenaran adalah kesesuaian arti dengan fakta yang telah diakui kebenarannya dan tergantung kepada aspek manfaat tidaknya bagi kehidupan manusia. Sedangkan kebenaran yang dibawa oleh wahyu diyakini bersifat absolute dan mutlak, sedang kebenaran yang diperoleh melalui akal bersifat relative, mungkin benar dan mungkin salah. Jadi, apa yang diyakini atas dasar pemikiran mungkin saja tidak benar karena ada sesuatu di dalam nalar yang salah. Demikian pula apa yang diyakini karena pengamatan belum tentu benar karena penglihatan mungkin saja mengalami penyimpangan. Karena itu, kebenaran mutlak hanya milik Tuhan. ${ }^{2}$ Dalam dunia metafisis dan realitas mutlak yang trasendental, bahwa parameter kebenaran ilmu itu adalah teks wahyu (al-Qur'an dan al-Hadith) yang maknanya diketahui secara pasti menurut standar ijma' dan logika. ${ }^{3}$

1 A. Susanto, Filsafat Ilmu "Suatu Kajian dalam Dimensi Ontologis, Epistemologis dan Aksiologis", (Jakarta: PT. bumi Aksara), 139

2 Tim Penyusun MKD IAIN Sunan Ampel, Pengantar Filsafat (Surabaya: IAIN Sunan Ampel Press, 2011), 89

3 Saeful Anwar, Filsafat Ilmu Dimensi Ontologi, dan Aksiologi, (Bandung: Pustaka Setia, 2007), 295 
Istilah ilmu pengetahuan, menurut etimologi diambil dari bahasa Arab " alima, yalamu, 'ilman" yang berarti mengerti atau memahami benar-benar. ${ }^{4}$ Sedangkan menurut terminologi adalah usaha pemahaman manusia yang disusun dalam satu sistem mengenai kenyataan, struktur, pembagian, bagian-bagian dan hukum-hukum tentang hal ihwal yang diselidiki (alam, manusia dan agama) sejauh yang dapat dijangkau daya pemikiran yang dibantu pengindraaan manusia itu, yang kebenarannya diuji secara empiris, riset dan eksperimental. ${ }^{5}$ Berdasarkan penjelasan di atas, dapat disimpulkan bahwa ilmu pengetahuan adalah suatu pengetahuan yang disusun secara sistematis sebagai hasil penelitian dengan menggunakan metode tertentu.

\section{Teori Religiusisme}

Manusia adalah makhluk pencari kebenaran, dalam perenungannya akan menemukan tiga bentuk eksistensi, yaitu agama, ilmu pengetahuan, dan filsafat. Agama mengantarkan pada kebenaran, dan filsafat membuka jalan untuk mencari kebenaran. Sedangkan ilmu pengetahuan pada hakikatnya adalah kebenaran itu sendiri. ${ }^{6}$

Dalam filsafat, untuk mendapatkan kebenaran hakiki manusia harus mencarinya sendiri dengan mempergunakan alat yang dimilikinya berupa segala potensi lahir dan batin. Sedangkan dalam agama, untuk mendapatkan kebenaran hakiki itu tidak hanya mencarinya sendiri, melainkan ia harus menerima hal-hal yang diwahyukan Tuhan, dengan kata singkat percaya atau iman. ${ }^{7}$ Jadi, Teori Religiusisme di sini adalah suatu kebenaran yang bersumber dari sabda Tuhan yang disampaikan melalui wahyu, dalam hal ini adalah al-Qur'an.

Walaupun antara kebenaran yang disajikan oleh agama mungkin serupa dengan kebenaran yang dicapai oleh filsafat, tetapi tetap agama tidak bisa disamakan dengan filsafat. Perbedaan ini disebabkan cara pandang yang berbeda. Di satu pihak agama mendasarkan diri kepada

${ }^{4}$ Luwis Ma'luf, al-Munjid fi al-Lughob wa al 'Alam (Beirut: Dār al-Mashriq, 2003), 526

5 Endang Saifuddin Anshari, Ilmu, Filsafat dan Agama, (Surabaya: PT. Bina Ilmu, 1987), 49-50

6 Mohammad Adib, Filsafat Ilmu (Yogyakarta: Pustaka Pelajar, 2010), 125

7 Tim Penyusun MKD IAIN Sunan Ampel, Pengantar Filsafat, 65 
kebenaran wahyu, di lain pihak filsafat berdasarkan penelitian yang menggunakan potensi manusiawi sebagai satu-satunya alat ukur kebenaran, yaitu akal manusia. Manusia tidak dapat hidup dengan benar hanya dengan kebenaran-kebenaran pengetahuan, ilmu dan filsafat, tanpa kebenaran agama.

\section{Al-Qur'an dan Ilmu Pengetahuan}

Tidak diragukan lagi, al-Qur'an adalah kitab suci umat Islam. Di dalamnya memuat berbagai ilmu pengetahuan yang kebenarannya mutlak serta keasliannya yang tak dapat disangsikan lagi telah memberi kedudukan istimewa kepada al-Qur'an di antara kitab-kitab Suci yang lain.

Sepuluh persen dari ayat-ayat al-Qur'an merupakan rujukan-rujukan kepada fenomena alam. ${ }^{8}$ Di masa sekarang banyak ditemukan orang yang mencoba menafsirkan ayat al-Qur'an dalam sorotan pengetahuan ilmiah modern. Tujuan utamanya adalah untuk menunjukkan mukjizat al-Qur'an dalam lapangan keilmuan untuk meyakinkan orang-orang non Muslim akan keagungan dan keunikan al-Qur'an, dan untuk menjadikan kaum Muslim bangga memiliki kitab agung seperti itu.

Pandangan yang menganggap al-Qur'an sebagai sebuah sumber seluruh pengetahuan bukanlah hal yang baru, sebab banyak ulama' besar kaum Muslim terdahulu berpandangan demikian. Diantaranya adalah Imam Ghazali, beliau berkata:

"Seluruh ilmu tercakup di dalam sifat-sifat Allah, dan al-Qur'an adalah penjelasan esensi dan perbuatannya. ${ }^{9}$ Prinsip ilmu-ilmu ini yang telah kami jelaskan dan yang belum kami spesifikasikan, bukanlah diluar al-Qur'an ,karena seluruh ilmu ini diraih dari salah satu lautan pengetahuan-Nya, yaitu lautan karya-Nya. Telah kami sebutkan bahwa al-Qur'an itu laksana lautan yang tak bertepi, dan bahwa sekiranya lautan itu menjadi tinta (untuk menjelaskan) kata-kata Tuhanku, sungguh lautan itu akan habis sebelum kata-kata Tuhan itu berakhir. Diantara perbuatan Allah yang (karena keluasannya dapat disebut) lautan perbuatan-Nya, misalnya

${ }^{8}$ Mahdi Ghulsyani, Filsafat Sains menurut al-Qur'an, terj. Agus Effendi (Bandung: Mizan, 1998), 137

9 Abu Hamid Muhammad Al-Ghazali, Ibya' 'Ulum al-Dìn, Dār al-Ma'rifah, Jilid V, 1 
adalah menyembuhkan dan menimbulkan penyakit, sebagaimana Allah menceritakan ucapan Ibrahim yang mengatakan, 'Ketika aku sakit Dia-lab yang telab menyembubkian aku' ... Perbuatan ini saja hanya dapat diketahui oleh orang yang mengetahui ilmu obat-obatan dengan sempurna, karean ilmu ini tidak berarti apa-apa selain pengetahuan tentang seluruh aspek penyakit sekaligus gejalanya, juga pengetahuan penyembuhan dan caracaranya. Diantara perbuatan Allah (juga) adalah penentuan pengetahuan (manusia) tentang matahari, bulan, dan pengetahuan tentang tingkatantingkatannya yang sesuai dengan waktu peredarannya, sebagaimana Allah SWT berfirman, Matahari dan bulan itu berjalan sesuai dengan peredarannya yang pasti, dan Dia atur perjalanan bulan itu sehingga kamu dapat belajat bagaimana cara menghitung tabun dan menetukan waktu ...

"Makna sesungguhnya gerakan-gerakan matahari dan bulan sesuai dengan peredarannya yang pasti, dan sesuai dengan gerhana yang terjadi pada keduanya, munculnya malam terhadap siang dan cara yang satu mengitari yang lain, hanya bisa diketahui oleh orang yang mengetahui komposisi langit dan bumi, dan ini sendiri adalah sebuah ilmu (yaitu astronomi)... Kami tidak bisa menceritakan perbuatan Allah dengan terinci sesuai yang ditunjukkan oleh al-Qur'an, karena akan menyita waktu yang panjang. Hanya sebuah isyarat kecocokannya saja yang mungkin diberikan (disini), dan ini telah kami lakukan ketika kami menyebutkan bahwa pengetahuan tentang perbuatan Allah itu adalah sebagian dari pengetahuan tentang Tuhan SWT. Keseluruhan tersebut mencakup rincian ini. Begitu pula, setiap pembagian ringkas yang kami sebutkan ini, jika dibagi lebih lanjut, akan bercabang-cabang pada banyak rincian lain.

"Maka, renungkanlah al-Qur'an itu dan carilah keagungan maknamaknanya, sehingga memungkinkan anda meraih pertemuan ilmu-ilmu klasik dan ilmu-ilmu modern dan seluruh permulaan-permulaannya didalamnya. Perenungan terhadap al-Qur'an ini hanya dimaksudkan untuk mencapai penggambaran ringkas ilmu-ilmu tersebut, sampai pengetahuan yang terinci, dan ini laksana samudera yang tak bertepi". ${ }^{10}$

Manusia harus memulai periode yang lama sebelum menjadi mampu

${ }^{10}$ Mahdi Ghulsyani, Filsafat Sains menurut al-Qur'an, 138 (Lihat. Abu hamid Muhammad al-Ghazali, The Jewel of the Qur'an, terj. Muhammad Abu al-Qasim, Routledge \& Kegan Paul, 1983, 45-48) 
memperoleh pengetahuan riil. (Dalam proses ini) Pengetabuan merrupakan sesuatu yang dating yang paling akbir, dengan melalui perantaraan indera. Khususnya indera penglihatan dan pendengaran dan lagi diatas segalanya melalui akal manusia. Ketika dilahirkan, manusia sebagai makhluk, belum disertai dengan pengetahuan. Manusia dilahirkan hanya disertai dengan kemampuan untuk menerima pengetahuan tetapi tidak dengan pengetahuan itu sendiri yang memang telah siap dilimpahkan kepadanya. ${ }^{11}$

\section{Ilmu Pengetahuan dalam Al-Qur'an dan Kebenarannya}

Alam, manusia dan binatang adalah dunia fisik, yaitu yang berhubungan dengan indera. Al-Qur'an bukanlah sebuah buku tentang ilmu pengetahuan, akan tetapi kitab petunjuk dan pencerahan. Rujukan al-Qur'an terhadap ilmu pengetahuan dimaksudkan untuk menarik perhatian manusia pada Pencipta yang Maha Mulia dan mendorong manusia agar berjuang mendekat kepada-Nya. ${ }^{12}$

Berulangkali Allah berfirman bahwa Dia-lah Yang Maha Benar dan sumber dari segala kebenaran. Al-Qur'an yang merupakan firmanNya adalah kitab kebenaran, diturunkan sebagai petunjuk, rahmat dan cahaya bagi semesta alam. Disamping itu juga menegaskan, bahwa Islam adalah agama yang benar. Dengan ajaran Islam yang tertuang dalam alQur'an, Allah memutuskan berbagai problematika asasi yang tidak dapat dipecahkan dengan akal manusia. ${ }^{13} \mathrm{Hal}$ ini sebagaimana firman Allah:

$$
\text { فذلكم الله ربّكم الحقّ فماذا بعد الحق إلا الضّّلال فأنّى تصرفون } 14
$$

Artinya: "itulah Dia tuhan kamu Yang Maha Benar. Tidak ada sesudah kebenaran itu kecuali kesesatan. Bagaimana kamu dapat dipalingkan dari kebenaran itu"

Agama senantiasa memotivasi pengembangan ilmu pengetahuan. Ilmu pengetahuan akan membahayakan umat manusia jika tidak dikekang dengan agama. Dari sini dapat diambil konklusi, bahwa ilmu

${ }^{11}$ H.G. Sarwar, Filsafat al-Qur'an, (Jakarta: CV. Rajawali, 1990), 127

${ }^{12}$ Mahdi Ghulsyani, Filsafat Sains menurut al-Qur'an, 78

${ }^{13}$ Fathurrahman Jamil, Filsafat Hukum Islam, (Jakarta: Logos Wacana Ilmu, 1999), 35

${ }^{14}$ Al-Qur'an, 10: 32 
tanpa agama buta, dan agama tanpa ilmu lumpuh. ${ }^{15}$ Berikut ini adalah beberapa fenomena ilmu pengetahuan yang disebutkan dalam al-Qur'an, yang akan dikaji dengan menggunakan Teori Religiusisme.

\section{- Urutan-urutan antara siang dan malam}

Pada waktu manusia menganggap bahwa bumi itu pusat alam dan matahari bergerak di sekitar bumi, siapa yang tidak menyebutkan matahari dalam membicarakan urut-urutan antara siang dan malam? Tetapi hal semacam itu tidak terdapat dalam al-Qur'an. Al-Qur'an membicarakan urut-urutan siang dan malam sebagai berikut:

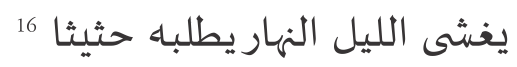

Artinya: "Dia menutupkan malam kepada siang yang mengikutinya dengan cepat".

$$
\text { واية لهم الليل نسلح مناه النهار فإذا هم مظلمون } 17
$$

Artinya: "Dan suatu tanda kekuasaan Allah bagi mereka adalah malam. Kami tanggalkan siang dari malam itu, maka dengan serta merta mereka dalam kegelapan ".

\section{- Langit yang mengembang}

Menurut Al Qur'an langit diluaskan/mengembang. Dan inilah kesimpulan yang dicapai ilmu pengetahuan masa kini. Sejak terjadinya peristiwa Big Bang, alam semesta telah mengembang secara terusmenerus dengan kecepatan maha dahsyat. Para ilmuwan menyamakan peristiwa mengembangnya alam semesta dengan permukaan balon yang sedang ditiup. Hingga awal abad ke-20, satu-satunya pandangan yang umumnya diyakini di dunia, ilmu pengetahuan adalah bahwa alam semesta bersifat tetap dan telah ada sejak dahulu kala tanpa permulaan. Namun, penelitian, pengamatan, dan perhitungan yang dilakukan dengan teknologi modern, mengungkapkan bahwa alam semesta sesungguhnya

\footnotetext{
${ }^{15}$ Fathurrahman Jamil, Filsafat Hukum Islam, 38

${ }^{16}$ Al-Qur'an, 07: 54

${ }^{17}$ Al-Qur'an, 36:37
} 
memiliki permulaan, dan ia terus-menerus "mengembang". ${ }^{18}$

Dalam Al Qur'an, yang diturunkan 14 abad silam di saat ilmu astronomi masih terbelakang, mengembangnya alam semesta digambarkan sebagaimana berikut ini:

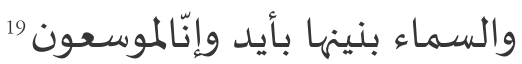

Artinya: "Dan langit itu Kami bangun dengan kekuasaan (Kami) dan sesungguhnya Kami benar-benar meluaskannya."

\section{- Gunung yang Bergerak}

Empat belas abad yang lalu, seluruh manusia menyangka gunung itu diam tidak bergerak. Namun dalam Al Qur'an disebutkan gunung itu bergerak. Gerakan gunung-gunung ini disebabkan oleh gerakan kerak bumi tempat mereka berada. Kerak bumi ini seperti mengapung di atas lapisan magma yang lebih rapat. Pergerakan kerak Bumi ini diketemukan setelah penelitian geologi yang dilakukan di awal abad ke-20. Para ilmuwan menjelaskan peristiwa ini sebagaimana berikut: Kerak dan bagian terluar dari magma, dengan ketebalan sekitar 100 $\mathrm{km}$, terbagi atas lapisan-lapisan yang disebut lempengan. Terdapat enam lempengan utama, dan beberapa lempengan kecil. Menurut teori yang disebut lempeng tektonik, lempengan-lempengan ini bergerak pada permukaan bumi, membawa benua dan dasar lautan bersamanya. Pergerakan benua telah diukur dan berkecepatan 1 hingga $5 \mathrm{~cm}$ per tahun. Lempengan-lempengan tersebut terus-menerus bergerak, dan menghasilkan perubahan pada geografi bumi secara perlahan. Setiap tahun, misalnya, Samudera Atlantik menjadi sedikit lebih lebar. ${ }^{20}$ Ayat al-Qur'an yang menyebutkan gunung bergerak adalah:

$$
\text { وترى الجبال تحسبها جامدة وهي تمرّ مرّ السحاب } 21
$$

Artinya: "Dan kamu lihat gunung-gunung itu, kamu sangka dia tetap di tempatnya, padahal ia berjalan sebagai jalannya awan”.

\footnotetext{
${ }^{18}$ http://syiarislam.wordpress.com/2007/11/07/keajaiban-al-Quran-dan-ilmu${ }^{19} \mathrm{Al}$-Qur'an, 51: 47

${ }^{20}$ http://syiarislam.wordpress.com/2007/11/07/keajaiban-al-Quran-dan-ilmu${ }^{21} \mathrm{Al}-\mathrm{Qur}$ an, 27: 88
} 


\section{- Langit dan Bumi awalnya adalah satu dan Asal mula kehidupan}

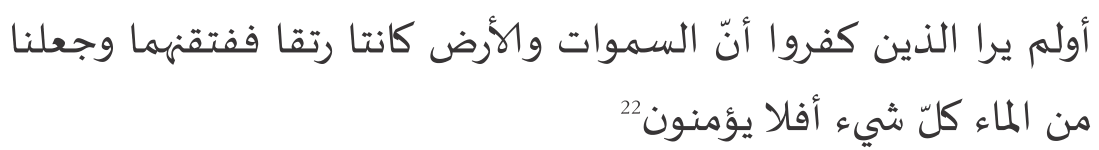

Artinya: "Dan apakah orang-orang kafir tidak mengetahui bahwasanya langit dan bumi itu keduanya dahulu adalah suatu yang padu, kemudian kami pisahkan antara keduanya, dan dari pada air kami jadikan segala sesuatu yang hidup”.

Pada ayat tersebut mengandung dua pemahaman tentang fenomena alam. Pertama, ayat tersebut menyatakan bahwa langit dan bumi tadinya adalah suatu gumpalan. Dan pada suatu masa yang tidak diterangkan oleh al-Qur'an, gumpalan tersebut dipecahkan atau dipisah oleh Allah ${ }^{23}$. Saat itu orang tidak ada yang tahu bahwa langit dan bumi itu awalnya satu. Ternyata ilmu pengetahuan modern seperti teori Big Bang menyatakan bahwa alam semesta (bumi dan langit) itu dulunya satu, kemudian akhirnya pecah menjadi seperti sekarang ini.

Kedua, Ayat tersebut bisa berarti bahwa tiap-tiap benda hidup, diciptakan dari air sebagai bahan baku, atau tiap-tiap benda hidup berasal dari air. Kedua arti tersebut sesuai dengan Sains modern yang mengatakan bahwa kehidupan itu berasal dari air, atau air itu adalah bahan pertama untuk membentuk sel hidup. Tanpa air tak akan ada kehidupan. Yang diterjemahkan dengan "air" adalah kata bahasa Arab mā', yang bisa berarti air hujan, air laut dan air sperma. ${ }^{24}$

\section{- Segala Sesuatu diciptakan Berpasang-pasangan}

Al-Qur'an yang berulang-ulang menyebut adanya pasangan dalam alam tumbuh-tumbuhan, juga menyebut adanya pasangan dalam rangka yang lebih umum, dan dengan batas-batas yang tidak ditentukan.

"Maha Suci Tuhan yang telah menciptakan pasangan-pasangan semuanya baik dari apa yang ditumbuhkan oleh bumi dan dari diri mereka maupun dari apa-apa yang mereka tidak ketahui." 25

\footnotetext{
${ }^{22}$ Al-Qur'an, 21: 30

${ }^{23}$ M. Quraisy Shihab, Membumikan al-Qur'an, (Bandung: Mizan, 1998), 50

${ }^{24}$ Maurice Bucaille, Bibel, al-Qur'an dan Sains Modern, 276-277

${ }^{25}$ al-Qur'an,36:36
} 
Kita dapat mengadakan hipotesa sebanyak-banyaknya mengenai arti hal-hal yang manusia tidak mengetahui pada zaman Nabi Muhammad. Hal-hal yang manusia tidak mengetahui itu termasuk di dalamnya susunan atau fungsi yang berpasangan baik dalam benda yang paling kecil atau benda yang paling besar, baik dalam benda mati atau dalam benda hidup. Yang penting adalah untuk mengingat pemikiran yang dijelaskan dalam ayat itu secara rambang dan untuk mengetahui bahwa kita tidak menemukan pertentangan dengan Sains masa ini.

Meskipun gagasan tentang "pasangan" umumnya bermakna laki-laki dan perempuan, atau jantan dan betina, ungkapan "maupun dari apa yang tidak mereka ketahui" dalam ayat di atas memiliki cakupan yang lebih luas. Kini, cakupan makna lain dari ayat tersebut telah terungkap. Ilmuwan Inggris, Paul Dirac, yang menyatakan bahwa materi diciptakan secara berpasangan, dianugerahi Hadiah Nobel di bidang fisika pada tahun 1933. Penemuan ini, yang disebut "parité", menyatakan bahwa materi berpasangan dengan lawan jenisnya: anti-materi. Anti-materi memiliki sifat-sifat yang berlawanan dengan materi. Misalnya, berbeda dengan materi, elektron anti-materi bermuatan positif, dan protonnya bermuatan negatif. Fakta ini dinyatakan dalam sebuah sumber ilmiah sebagaimana berikut:

“...setiap partikel memiliki anti-partikel dengan muatan yang berlawanan ... dan hubungan ketidakpastian mengatakan kepada kita bahwa penciptaan berpasangan dan pemusnahan berpasangan terjadi di dalam vakum di setiap saat, di setiap tempat."

Semua ini menunjukkan bahwa unsur besi tidak terbentuk di Bumi, melainkan dibawa oleh meteor-meteor melalui letupan bintang-bintang di luar angkasa, dan kemudian "dikirim ke bumi”, persis sebagaimana dinyatakan dalam ayat tersebut. Jelas bahwa fakta ini tak mungkin diketahui secara ilmiah pada abad ke-7, di saat Al Qur'an diturunkan.

Contoh di atas hanyalah sebagian kecil dari keajaiban Al Qur'an yang ada dan ternyata sesuai dengan ilmu pengetahuan modern. Jelas Al Qur'an itu benar dan tak ada keraguan di dalamnya.

"Kitab Al Quran ini tidak ada keraguan padanya; petunjuk bagi mereka yang bertaqwa". ${ }^{26}$

\footnotetext{
${ }^{26}$ al-Qur'an, 2:2
} 
Jika agama lain bisa punya lebih dari 4 versi kitab suci yang berbeda satu dengan lainnya, maka Al Qur'an hanya ada satu dan tak ada pertentangan di dalamnya:

"Maka apakah mereka tidak memperhatikan Al Quran? Kalau kiranya Al Quran itu bukan dari sisi Allah, tentulah mereka mendapat pertentangan yang banyak di dalamnya." ${ }^{27}$

Keutamaan agama Islam ialah bahwa agam itu membuka pentu selebar-lebarnya bagi kaum muslimin untuk memperoleh pengetahuan. Ia mendorong mereka mendalaminya dan meraih kemajuan, menerima perkembangan baru keilmuan yang sesuai dengan kemajuan zaman

Al-Qur'an sejalan dengan ilmu pengetahuan, atau sesuai dengan semua cabang ilmu alam, dalam pengertian yang meluruskan aqidah. Al-Qur'an tidak menghendaki kemungkinan adanya pertentangan dan keraguan ketika terjadinya perubahan kaidah-kaidah itu mengikuti hasil penemuan baru yang merobohkan pemikiran lama, atau sewaktu buktibukti yang meyakinkan menghapus dugaan-dugaan yang meragukan. ${ }^{28}$

\section{Penutup}

Dari penjelasan diatas, maka dapat di tarik sebuah pemahaman, bahwa kebenaran ilmu pengetahuan dalam teori religiusisme adalah suatu kebenaran yang bersumber dari sabda Tuhan yang disampaikan melalui wahyu, dalam hal ini adalah al-Qur'an. Sebagian dari ajaran al-Qur'an adalah menyangkut tentang kehidupan manusia di alam raya ini, termasuk perkembangan ilmu pengetahuan. Segi lain yang tidak kurang pentingnya untuk dibahas dalam masalah al-Qur'an dan ilmu pengetahuan adalah kandungan ayat-ayatnya di tengah-tengah perkembangan ilmu. Salah satu bukti tentang kebenaran al-Qur'an adalah ayat-ayatnya yang berbicara tentang hakikat-hakikat ilmiah yang tidak dikenal pada masa turunya, namun terbukti kebenarannya di tengah-tengah perkembangan ilmu. Misalnya; langit yang mengembang, gunung yang bergerak, langit dan bumi awalnya adalah satu dan asal mula kehidupan, dan reproduksi tumbuh-tumbuhan.

${ }^{27}$ al-Qur'an, 4:82

${ }^{28}$ Abbas Muhammad al-Aqqad, Filsafat al-Qur'an, (Jakarta: Pustaka Firdaus, 1996), 16 


\section{Daftar Pustaka}

Adib, Mohammad. Filsafat Ilmu. Yogyakarta: Pustaka Pelajar, 2010.

Anwar, Saeful, Filsafat Ilmu Dimensi Ontologi, dan Aksiologi, Bandung: Pustaka Setia, 2007.

Anshari, Endang Saifuddin, Ilmu, Filsafat dan Agama, Surabaya: PT. Bina Ilmu, 1987.

Aqqad (al), Abbas Muhammad, Filsafat al-Qur'an, Jakarta: Pustaka Firdaus, 1996.

Bucaille, Maurice. Bibel, al-Qur'an dan Sains Modern, terj. Rasjidi. Jakarta: Bulan Bintang, 1979.

Departemen Agama RI., Al-Qur'an Dan Terjemahannya, Bandung: J-Art, 2005.

Ghazali (al), Abū Ḥamid Muhammad, Ihya' 'Utum al-Dìn, Dār al-Ma' rifah, Jilid V.

Ghulsyani, Mahdi. Filsafat Sains menurut al-Qur'an, terj. Agus Effendi. Bandung: Mizan, 1998.

http://syiarislam.wordpress.com/2007/11/07/keajaiban-al-quran-danilmu-

Jamil, Fathurrahman. Filsafat Hukum Islam. Jakarta: Logos Wacana Ilmu, 1999.

Ma'luf, Luwis. Al-Munjid fi al-Lughoh wa al 'Alam. Beirut: Dār al-Mashriq, 2003.

Saifuddin Anshari, Endang. Ilmu, Filsafat dan Agama. Surabaya: PT. Bina Ilmu, 1987.

Sarwar H.G., Filsafat al-Qur'an, Jakarta: CV. Rajawali, 1990.

Shihab, M. Quraisy. Membumikan Al-Qur'an. Bandung: Mizan, 1998

Susanto, Ahmad. Filsafat Ilmu "Suatu Kajian dalam Dimensi Ontologis, Epistemologis dan Aksiologis". Jakarta: PT. bumi Aksara.

Tim Penyusun MKD IAIN Sunan Ampel, Pengantar Filsafat. Surabaya: IAIN Sunan Ampel Press, 2011. 